EDITORIAL

\title{
A Enfermagem, a ética e a modernidade
}

O mundo do século vinte e um certamente não abrirá mão da modernidade. As novas tecnologias invadirão não só o mercado que nutre as grandes empresas, mas também os domicílios de parte da sociedade mais abastada.

A educação cada vez mais será valorizada na medida em que introduzir o uso de aparelhos facilitadores da comunicação ágil e permanentemente atualizada.

A prestação de serviços de saúde contará para controle e avaliação da clientela, com métodos e técnicas sofisticados e instrumentos de alta precisão, para exames que se tornam cada vez menos invasivos e perniciosos ao organismo humano. O robô substituirá o trabalhador humano em muitas situações.

O controle do usuário dos Serviços de Saúde dotado de privilegiado poder aquisitivo será objeto de estudos da área de comunicação. Esta sempre atenta à clientela geradora de lucros, com toda a certeza criará um sistema de propaganda eficiente para atraí-lo ao quadro de sócios das multinacionais prestadoras de serviços de altos custos. Os homens serão valorizados pelo que têm, e pelo que sabem, e pelo seu estado de saúde.

Todavia, este mesmo mundo terá aumentado o seu minoritário contingente de grupos humanos que buscam a cura dos males do corpo e da mente por processos naturais. Para isso recorrem a preceitos da antigüidade, buscam exemplos de manutenção e compreensão da vida em culturas orientais e em práticas culturais de diferentes povos. Crêem que a manutenção da saúde pode ser viabilizada pelas trocas de energia com elementos da natureza.

A aura humana será objeto de estudos avançados e muitos pensarão em cura e equilíbrio de corpo e mente a partir de intervenções físicas muito diferentes das que habitualmente usamos neste século.

Há, ainda, aqueles que asseguram a existência de outras vidas no universo e a possibilidade de realizar contatos com os extraterrestres. 
Com base neste contexto, indaga-se: - Como estará se posicionando o enfermeiro, considerando o profissional da preservação da saúde e defensor da vida?

Enfim, a sedutora modernidade, nem sempre é justa e universal, nem sempre é tratada a partir de princípios fundados nas necessidades do próprio ser. Como viver os benefícios dela advindos com base numa ética humanista, sem a vergonha de se encontrar entre minorias privilegiadas?

Se possível fosse, aqui e agora, avançar no tempo e, hipoteticamente, exercitar um mergulho no futuro, poder-se-ia imaginar o enfermeiro como o profissional capaz de usar os recursos sofisticados do novo tempo e, simultaneamente, compreender o viver das pessoas sob seus cuidados - usando também técnicas e medidas naturais - sem considerar absurdo a conjugação de propostas, hoje quase sempre consideradas antagônicas.

$\mathrm{Na}$ atualidade, este comportamento profissional poderia causar estranheza aos cientistas que aceitam o conhecimento advindo da racionalidade, onde as sensações e sentimentos humanos foram excluídos ou, no mínimo, controlados no seu processo de formulação.

Assim me parece que o grande desafio do novo tempo é o da justa distribuição dos bens da humanidade, do desenvolvimento da solidariedade sem fronteiras - movimento este que não será fácil, pois implicará na compreensão do homem no seu destino planetário, vinculo mais plenamente, na medida em que for capaz de dividir seus bens e acompatilhar os seus dons.

$\mathrm{O}$ que se vislumbra, ainda, independentemente do que possa ocorrer no campo das criações, é a grande aventura de mulheres e homens se tornarem capazes de fazer uso de todo potencial que o seu próprio corpo e mente lhe presenteia desde o seu nascimento e a natureza pródiga lhe ensina sem qualquer cobrança.

Maria Therezinha Nóbrega da Silva 